\title{
Anesthesia for Successful Surgical Separation of Conjoined Twins in West Africa : A Big Anesthetic Challenge
}

Traore $\mathrm{MM}^{1 *}$, Diop $\mathrm{MN}^{1}$, Gueye $\mathrm{D}^{1}$, BA ${ }^{1}$, Ndoye $\mathrm{A}^{1}$, Diop $\mathrm{FNM}^{1}$, Diallo $\mathrm{M}^{2}$, Seye $\mathrm{M}^{3}$, Gaye $\mathrm{I}^{3}$, Gassama $\mathrm{O}^{3}$, Leye $\mathrm{PA}^{3}$ and Diouf $\mathrm{E}^{3}$

${ }^{1}$ Children Hospital Albert Royer, Senegal

${ }^{2}$ Maternity of Pikine National Hospital, Senegal

${ }^{3}$ University Hospital Aristide Le Dantec, Senegal

Submission: September 19, 2019; Published: September 25, 2019

*Corresponding author: Traore Mamadou Mour, Senior Pediatric Anesthesiologist, Children Hospital Albert Royer, Dakar, Senegal

Summary

The birth of conjoined twin is an uncommon et rare situation. In social african context that matter raises affective and psycho-social issues, then often babies are sended abroad for surgical separation. Here, we report the anesthetic management for successful surgical separation of thoraco-omphalopagus conjoint twins in low ressources country, one of them still alive. We relate the anesthetic challenges giving a high risky anesthesia in a particular situation of two individuals at the same table and operating room with two surgical teams. The importance of a multidisciplinary approach in the preoperative evaluation and planning, the induction and airway access, the type of complication such as blood lost, cardiorespiratory failure in the postoperative, are mentioned.

Keywords: Anesthesia; Africa; Conjoined twins; Surgical separation; Thoraco-omphalopagus

\section{Introduction}

Newborn conjoined twins is an uncommon phenomenon worldwide. Its incidences range from $1 / 50000$ to $1 / 250000$ live births [1], with higher rates in Africa and South-West Asia. However, about $40-60 \%$ of the cases are stillborn [1,2]. In our social african context, this phenomenon raises affective and psycho-social issues giving the mother the perception of delivering monster kids. At this moment, there is no identified cause. However, two theories evolve. The most accepted theory indicates the fact of an incomplete split of the fertilized ovum during its congenital development [3]. Female predominance is estimated at $75 \%$. The separation surgery is a high risk surgical approach with a short-term life-threatening outcome interesting one or both infants. In this paper, we report the achievement of an anesthetic management of a thoraco-omphalopagus conjoined twins condition in a low income Sub-Saharan Africa country.

\section{Clinical case}

Parental consent was obtained in regard to the explanation of the patients' clinical presentation.

\section{Operative plan}

A 25-year-old primigravida woman conducted a full-term monochorial and monoamniotic conjoined twins pregnancy. $\mathrm{C}$-section was performed on the basis of a severe pre-eclampsia and was referred to our facility from the suburb of Dakar. The diagnosis was not set in antenatal period, it was rather fortuitous during the C-Section approach. The two babies were linked by their thorax and abdomen at the ombilic. They were thoraco-omphalopagus conjoined twins in usuel classification. Pre-operative assessment allowed to set them apart by S1 and S2. Physical examination didn't find remarkable morphological abnormalities. The overall birth weight was estimated at $4,3 \mathrm{~kg}$ with a normal Apgar score (Figure1). CT-scan was performed for shared organ assessment and revealed attachement of the 2 livers, an elevation of the diaphragmatic cupolas and likely thoracic bones abnormalities (Figure 2). On S2 baby, heart ultrasound showed an interventricular communication with no precised character due to positionnal issues of the babies. The baryte enema investigation showed two distinct gastro-intestinal tracts 
without abnormality. Biochemical and haematological tests were unremarkable. No veinous route was set up and the feeding was carried out through baby bottle with mixed milk. On their bedside, they were assisted by their mother and a nurse for medical care. During the observational period, the family was enough prepared for the separation planned for the 47th day after birth. A multidisciplinary team gathering anesthesiologists, pediatric surgeons, neonatalogists and social workers was set up in regard to the operative act.

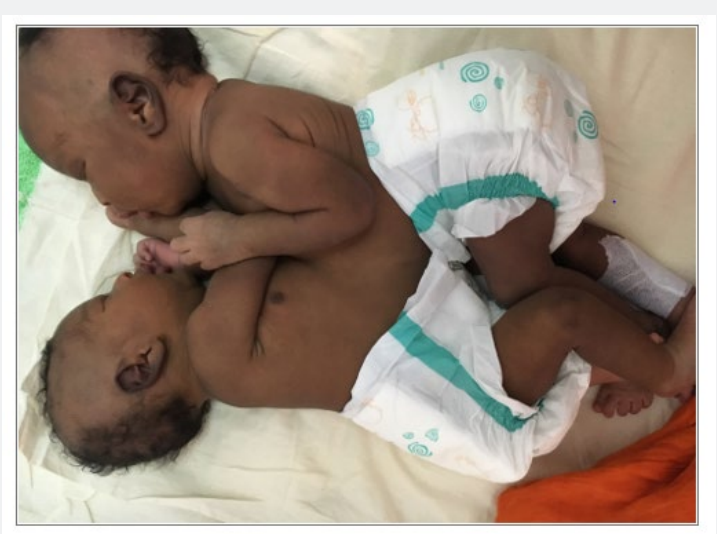

Figure 1: Physical examination didn't find remarkable morphological abnormalities. The overall birth weight was estimated at $4,3 \mathrm{~kg}$ with a normal Apgar score.

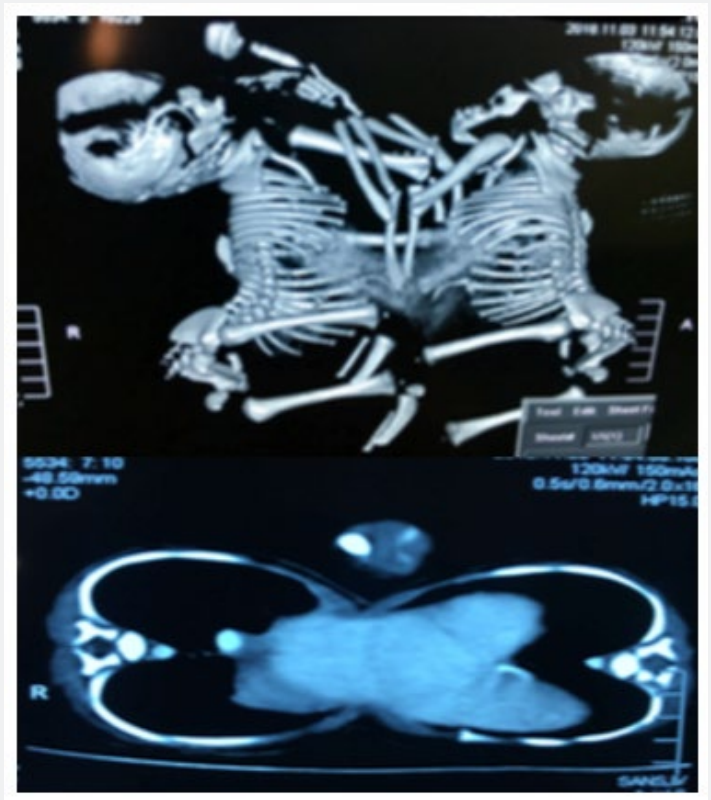

Figure 2: CT-scan was performed for shared organ assessment and revealed attachment of the 2 livers, an elevation of the diaphragmatic cupolas and likely thoracic bones abnormalities.

\section{Operative act}

The twins were installed on an operative table and warmed up through a warm touch device. Two gas masks were set (Mindray Wato EX 65 Pro, Primus). A separated monitoring was carried out and consisted on, for each twin, an ECG, non invasive pressure, pulse oxymeter, oral thermometer, urinary catheter and a capnograph. Each newborn had her own drip, prepared by the anesthetic nurse respecting the defined protocole. Two distinct peripheral venous routes were found with anesthetic induction alternatively performed on S2 then S1 after receiving oxygen.
Anesthetic agents consisted of Lidocaine $1 \mathrm{mg} / \mathrm{kg}$, Ketamine $0,2 \mathrm{mg} / \mathrm{kg}$, Magnesium 30mg/kg, Fentanyl $1 \mathrm{mcg} / \mathrm{kg}$ and Propofil $3 \mathrm{mg} / \mathrm{kg}$. Orotracheal intubation with tube $\mathrm{n}^{\circ} 3$ was alternatively carried out on S2 in supine position, while S1 was maintained on the air for a better approach of the airways (Figure 3). After intubation and fixation of the tube, Vecuronium $0,1 \mathrm{mg} / \mathrm{kg}$ was administered and they both were under assisted ventilation with oxygen/air mix up with FiO2 at 35\%. Sevofurane at 4\% (1,7 MAC) helped maintain anesthesia. Central subclavian veinous route set up failed under ultrasound because of the positionnal issues of the babies. Postoperative analgesia was performed through 
a peridural catheter for both. Surgical incision was carried out on the cutaneous bridge that related the two neonates. The surgery consisted of a separation of the two sternums, attached pericardiums and the two livers by an electrosurgical device. Blood loss was hard to estimate. However we appreciated it by the amount of compresses and the suction jar and rated at $150 \mathrm{ml}$ indicating a red blood cell transfusion and the administration of noradrenaline $1,4 \mathrm{mck} / \mathrm{kg} / \mathrm{min}$. After a complete separation, the surgery kept going on two separated tables in the same operating room with surgical and anesthetic team for each one.

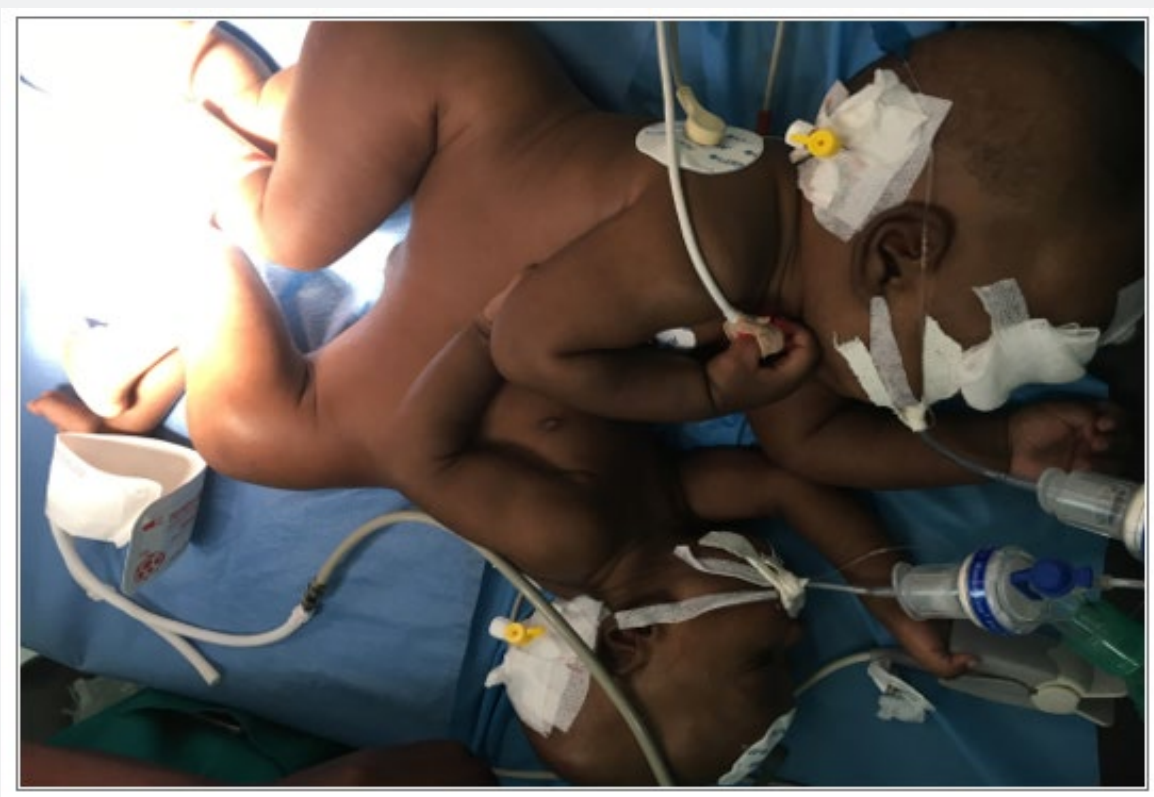

Figure 3: Orotracheal intubation with tube $\mathrm{n}^{\circ} 3$ was alternatively carried out on $\mathrm{S} 2$ in supine position, while $\mathrm{S} 1$ was maintained on the air for a better approach of the airways.

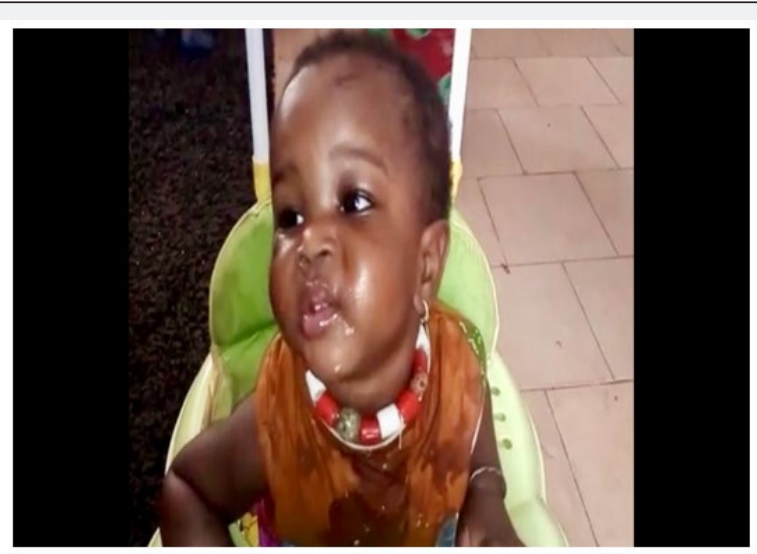

Figure 4: The evolution was characterized by the death of S2 in a multiple organ failure, cardiorespiratory and hepatocellular condition at day $4 . \mathrm{S} 1$ is living in good health and is 10 months old while reporting this review.

\section{Intensive care unit}

After a 2-hour-surgery, the newborns were extubated on the basis of neurological, haemodynamic and respiratory stability. There were sent for intensive care with central right subclavian veinous route set at the end of surgical approach. Postoperative analgesia encompassed Paracetamol, single dose of Ketoprofene, ketamine and continuous perfusion of ropivacine through peridural catheter and morphine titration. The evolution was characterized by the death of S2 in a multiple organ failure, cardiorespiratory and hepatocellular condition at day 4. S1 is living in good health and is 10 months old while reporting this review (Figure 4).

\section{Discussion}

Anesthesia for the separation of conjoined twins is uncommon [4]. In Africa, despite high incidence, there is a paucity of datas often due to the lack of adequate facilities to manage this kind of disorder. Most of these kind of patients are referred to countries with high-tech facilities because of a lack of resources and dramatic psychosocial impact. In our context, the birth of conjoined twins is a social tragedy. In West Africa, from 1963 
to 1978 , only 12 cases of siamese twins have been reported [5]. Eight cases were separated either in their country or abroad. The surgical approach succeeded on 6 among them. In 4 cases, a baby were lost either during surgery or sacrificed. In Africa, only two cases of non-separated siamese twins have been recorded [1] Surgical separation of conjoined twins is a high risk approach and remains very rare. Mortality is variable regarding the type and the shared organs. Since 1950, in $75 \%$ of cases, at least a twin have survived after the separation [6]. Our management was guided by the literature despite of a unique successful separation experience in Senegal of thoracopagus conjoined twins in 2003 by Ndoye and coll [7]. Besides the head surgeon, no other member of the team knew a kind of experience before. Multidisciplinary approach, as described by all teams, was an essential strategy that we followed as well. Morphological investigations were performed for a better surgical approach and consisted of CT-Scan with reconstitution allowing the classification to thoraco-omphalogus conjoined twins. According to Singh, this pattern represents 38\% of cases [8]. There shared the same liver, navel, with different biliary system. The gastro-intestinal tracts were distincts according to the baryte enema. Unlike to Kingston and coll [9], we didn't perform hepatic dynamic scintigraphy to make sure about the existence of separated biliary drainage, due to an inaccessibility. Hepatic fusion commonly occurs on omphalopagus twins and is rated at $80 \%$ of cases [10].

Regarding the haemodynamic state, the presence or absence of cross circulation is an essential data to take into account for anesthetic injection and haemodynamic outcome due to the splitup. Different methods can be conducted for cross circulation assessment. Kaniyil and coll assessed this condition while administrating atropine [11] whereas Toyoshima and coll chose indigo carmine [12]. Our patients had different circulatory system according to imaging investigations. The radiologists were sure in their investigations. In operative time that was confirmed by the absence of hypnotic effect on S2 after injecting propofol to S1. The management of the airways could sound difficult du to a faceto-face position, restricting the handling. In our series, intubation clinical simulation helped to be at ease during the surgery of this particularly uncommon condition. The anesthesia for conjoined twins is very challenging, including an intervention on the same operating table gathering many collaboraters, an intubation issue, pre-operative blood loss, and the presence of major malformative abnormalities fortuitously diagnosed due to limited resources in a low income country. For our patients, in the vires of preventing some events such as pre-operative blood loss tranexamic acid and red blood cell and plasma transfusion were conducted. The major operative moment was the separation of the livers that could lead to blood loss and haemodynamic instability. Noradrenaline was administrated after a vascular replenishment to lessen the damages. Greeberg and coll described the use of a caudal bloc associated to general anesthesia to separate omphalopagus twins [13]. According to them, post-operative anesthesia could allow an early extubation for the babies with high risk of breathing impairement. We preferred lumbar peridural analgesia for post-operative pain management. It has a large metameric spectrum for the thoraco-abdominal incision. Major respiratory impairement was the main post-operative issue associated with hepatocellular failure. It commonly occurs on thoraco-omphalopagus siamese twins [4]. S2 didn't survive to this complication associated with other comorbidities consisting of a large interventricular communication, a double-outlet right ventricle and circumferential pericardial effusion. His death occured at the 4 th day after surgery.

\section{Conclusion}

The anesthesia for the separation of siamese twins is very challenging. It requires an optimal work-group gathering different specialists. Surgical procedure simulation before the operative act is essential for an unexperimented team regarding this situation. Despite a context of limited resources in Sub-Saharan Africa, the separation of thoraco-omphalopagus twins remains possible provided that a good assessment of common organs is performed.

\section{References}

1. Mian A, Gabra NI, Sharma T, Topale N, Gielecki J, et al. (2017) Conjoined twins: From conception to separation, a review. Clin Anat. 30(3): 385396.

2. Montandon D (2015) The unspeakable history of thoracopagus twins' separation. ISAPS News 9(3): 46-49.

3. Kolli S Chalam (2009) Anesthetic management of conjoined twins' separation surgery. Indian J Anaesth 53(3): 294-301.

4. Singh M, Jacob R, Naik V, Baines D (2012) Separation of thoracoomphalopagus twins in a rural secondary hospital: Perioperative management. Indian J Anaesth 56(5): 442-447.

5. Mabogunje OA, JH Lawrie (1980) Conjoined twins in West Africa. Arch Dis Child 55(8): 626-630.

6. Mariatu BL, Valerie JC, Mike K, Alimamy PK, Michael MK, et al. (2017) A Triple Obstetric Challenge of Thoracopagus-Type Conjoined Twins, Eclampsia, and Obstructed Labor: A Case Report from Sub-Saharan Africa. Case Rep Obstet Gynecol.

7. Séparation des sœurs siamoises à Le Dantec : Une première réussie en Afrique Subsaharienne. Le soleil sénégal

8. Fagan CJ (1977) Antepartum diagnosis of conjoined twins by ultrasonography. AJR Am J Roentgenol 129(5): 921-922.

9. Kingston CA, McHugh K, Kumaradevan J, Kiely EM, Spitz L (2001) Imaging in the preoperative assessment of conjoined twins. Radiographics 21(5):1187-208.

10. Spitz L, Kiely EM (2002) Experience in the management of conjoined twins. Conjoined twins. Br J Surg 89(9): 1188-1192.

11. Kaniyil S, Pavithran P, Mubarak KK, Mohamed T (2016) Anaesthetic challenges in conjoined twins' separation surgery. Indian J Anaesth 60(11): 852-855

12. Toyoshima M, Fujihara T, Hiroki K, Namatame R, Ka K, et al. (1993) Evaluation of cross circulation in conjoined twins. Masui 42(9): 13471350.

13. Greenberg M, Frankville DD, Hilfiker M (2001) Separation of omphalopagus conjoined twins using combined caudal epiduralgeneral anesthesia. Can J Anaesth 48(5): 478-482. 
Your next submission with Juniper Publishers will reach you the below assets

- Quality Editorial service

- Swift Peer Review

- Reprints availability

- E-prints Service

- Manuscript Podcast for convenient understanding

- Global attainment for your research

- Manuscript accessibility in different formats ( Pdf, E-pub, Full Text, Audio)

- Unceasing customer service

Track the below URL for one-step submission https://juniperpublishers.com/online-submission.php 